\title{
Deep water warming in lakes: an indicator of climatic change
}

\author{
Walter AMBROSETTI* and Luigi BARBANTI \\ CNR Istituto Italiano di Idrobiologia, L.go V. Tonolli 50, 28922 Verbania-Pallanza, Italy \\ *e-mail corresponding author: w.ambrosetti@iii.to.cnr.it
}

\begin{abstract}
The deep waters of Lake Maggiore, Italy $\left(z_{\max }=370 \mathrm{~m}\right)$ contain a sort of "climatic memory", represented by variations in the caloric content, which has been located in time and space, and its energetic value calculated on the basis of the depth of the winter mixing, the heat exchange in deep waters and the $K_{z}-N^{2}$ correlation's during the summer stratification. This analysis, relating to the period 1963-1998, demonstrates that the caloric content in the hypolimnion at the end of the limnological year, i.e. when deep waters are formed, depends strictly on winter meteorological parameters (e.g., wind run, air temperature and solar radiation), as well as on the quantity of heat that can reach the deep layers before and after the onset of thermal stratification. The amount of heat that can reach the deep hypolimnion is around 2-4\% of the total heat budget of the lake; while its percentage is small, this quantity of heat can assume considerable importance, and lead to a progressive increase in the heat content of deep waters. The same percentage has been found in the other deep Italian lakes in the sudalpine region, i.e. lakes Como, Iseo, Orta and Garda ( $z_{\text {max }}$ between 143 and 410 $m$ ). All the lakes also have the same temporal evolution of the climatic memory: both the increasing overall trend and the variations (both positive and negative) occur simultaneously. The pattern we observed is quite similar to that found in historical series of deep water temperatures in lakes in Central Italy (L. Bolsena), North of the Alps, equatorial Africa (L. Victoria) as well as in the Mediterranean below a depth of $2000 \mathrm{~m}$ and in the Greenland Sea at depths between 200 and $2000 \mathrm{~m}$. Such a world-wide distribution of the phenomenon suggests that it may be regarded as part of an ongoing process of global climate change.
\end{abstract}

Key words: deep lakes, vertical mixing, long-term trend of heat content, climatic memory

\section{INTRODUCTION}

As a consequence of the climatic changes which are currently affecting our planet, the relationships among the different types of energy exchange between surface and atmosphere in large water bodies are also changing. The great thermal capacity of water means that deep lakes and seas can store large quantities of heat which is distributed to the various depths on the basis of their morphometric and hydrodynamic characteristics. The processes of storing and losing this energy follow a seasonal cycle, with longer-term trends and fluctuations. Lake and sea water masses can therefore act as filters (Livingstone 1993) as regards their daily, seasonal, annual and pluriannual temperature changes, with these cycles becoming more and more differentiated with depth. In sufficiently deep water bodies, the temperatures of the profundal layers are hardly or not at all influenced by daily temperature changes; they are rather more affected by seasonal changes, while long-term changes are easier to detect.

Deep waters are therefore able to retain a "climatic memory", which records information about their situation in the past. If this memory is accessible over lengthy periods, valuable information may be acquired on climatic changes in the past and predictions for the future may be made.

One of the most evident and most important responses in the physical, chemical and biological func- tioning of aquatic ecosystems, the mixing depth attained during the winter turnover, has been the object of particular attention (Ambrosetti \& Barbanti 1998). This hydrodynamic feature is especially important in deep lakes in temperate latitudes, including European water bodies north and south of the Alps. As with all water bodies, including seas (Bettoux et al. 1990), the winter temperature of the deepest layers mirrors the average climatic conditions of the season, since these conditions are typically shaped in this period of the year. For example, in the relatively deep perialpine lakes, classified as warm monomictic according to Hutchinson (1957), a full winter turnover occurs only at the end of particularly cold and windy winters; in other years the mixed layer is less deep, but in any case is always dependent on the climatic conditions. In this sense the definition of holo-oligomixis for these lakes is justified.

Since a full turnover is more an exception than the norm in deep lakes, the above analysis should be taken as referring to those water layers which most precisely reflect the evolution of climatic conditions; these water masses have a different depth from year to year, as a result of the extent of the turnover at the end of the limnological winter. As a consequence of this, the thickness of the part of the hypolimnion affected, containing part of the information on the climatic changes occurring between two turnovers, varies from year to year, and its evolution in time should be considered in detail. While the formation of the hypolimnion is the primary result of vertical mixing, other mechanisms occurring during 
or just after the limnological winter are of considerable importance. These mechanisms are not the result of convective motions, even though they are always associated with climatic variations, but are caused by the input of water from the tributaries, either cold and oxygenated or warmer but very dense (Meybeck et al. 1991; Barbanti \& Ambrosetti 1990; Sossau \& Pechlader 1988); they are also caused by particular conveyor belt currents arising in the lake (Ambrosetti et al. 1982) which can radically change the structures of the hypolimnion. motions, were evaluated along the Lake Maggiore water column for the period from 1951 to 1998 (Fig. 1). Our estimates were based on the vertical profiles $(0-370 \mathrm{~m})$ of water temperature and of the concentrations of dissolved $\mathrm{O}_{2}$, nitrate and silicate, used as tracers of water mixing. The graph shows that a complete mixing of the waters has occurred only on three occasions, namely in 1956, 1963 and 1970. (Barbanti \& Ambrosetti 1990; Vollenweider 1964).

Up to 1970 , then, the cycle was of approximately 7 years. In the period since then, the turnover has reached

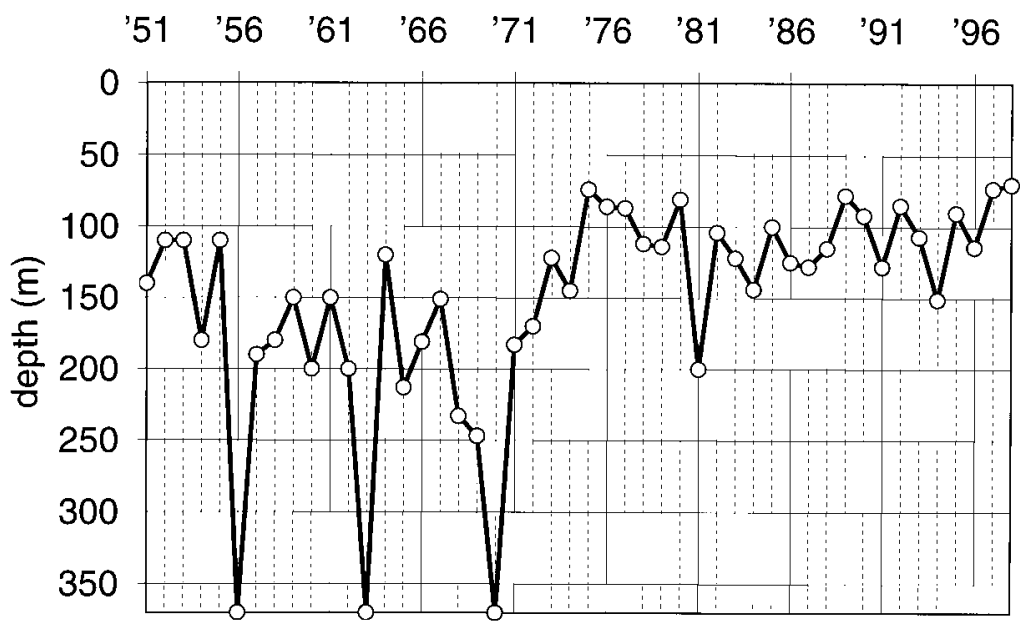

Fig.1. Depths of vertical mixing of Lake Maggiore waters at the end of the limnological winter in the period 1951-1998.

All the observations (Michalsky \& Lemmin 1995) suggest that wind-induced mixing is not the dominant process in the warming phase. In defining the deep layer containing the climatic memory, this paper evaluates the quantities of energy which penetrate successive depth layers, so as to identify the water masses affected by warming and cooling as the seasons evolve. We therefore made a close examination of the succession of thermal events in Lake Maggiore and in the other Italian lakes (Como, Garda, Iseo and Orta) for which we have a series of thermal data going back some time. We wanted to verify the effective capacity of the waters of deep lakes for retaining a "climatic memory" independent of the specific geographic, morphometric and hydrological characteristics of each lake, with the ultimate aim of using this parameter as a sensitive indicator of ongoing climate changes. We therefore focussed on identifying and quantifying their "climatic memory" and the shortand long-term processes which affect it, through the winter mixing, and the heat transfer to the deep layer brought about by the tributaries and by the wind.

\section{WINTER VERTICAL MIXING ON LAKE MAGGIORE}

The heat distribution in lakes depends largely on the depth of the vertical mixing at the end of the limnological winter These depths, due exclusively to convective a maximum depth of $200 \mathrm{~m}$ in only one year (1981) and depths of between only 50 and $150 \mathrm{~m}$ in other years. This means that the waters below $200 \mathrm{~m}$ date back to 1970 , i.e. are 28 years old. This is not to say, however, that subsequent modifications due to particular hydrodynamic phenomena cannot take place.

It should be pointed out that the full turnover of 1956 occurred at a temperature of $5.8^{\circ} \mathrm{C}$, whereas the temperature at turnover was $5.9{ }^{\circ} \mathrm{C}$ in 1963 and $6.0{ }^{\circ} \mathrm{C}$ in 1970 . This clearly shows the fact that a considerable amount of heat has been stored in the Lake Maggiore water mass in the last forty years and that the thermal conditions of previous winters have no longer been found in the lake. In effect, the quantity of heat present in the water mass at the end of the limnological winter of 1963 was about $4355 \mathrm{MJ} \mathrm{m}^{-2}$, increasing to $5193 \mathrm{MJ}$ $\mathrm{m}^{-2}$ in 1998; a further increase has been recorded in the last two years. A first inference is that the changed dynamic conditions of Lake Maggiore, particularly the absence of full turnovers since 1970, may depend precisely on this heat storage (Ambrosetti \& Barbanti 1998).

If the mixing is complete, a mass of new water is formed, i.e. defined in its chemical and physical characteristics. This newly-formed water mass can retain its properties for several years or for a few months, the duration of its life depending both on its initial state and 
on the kind of external forces that can bring about a change in its properties. This duration has been revealed for Lake Maggiore by an analysis of the heat content below $200 \mathrm{~m}$ depth, using an auto-correlation function, with increasing lags in the monthly data, for the series of data following the event of February 1963 and that of 1970 (Fig. 2). After the first event (A), 99\% level of significance (horizontal solid line) is retained for 4 years. This level is maintained only for 14 months after the mixing of 1970 (B), which was much less intense than the earlier one. Besides, all the episodes of decrease in $r$ shown in both the curves represent conditions of instability. Those in February are due to even partial winter mixing; in April-May and after October, they result from the onset of the stratification and de-stratification phases. In contrast, during the summer months the $r$ remains constant, suggesting a significant persistence on the bottom of water of old formation.

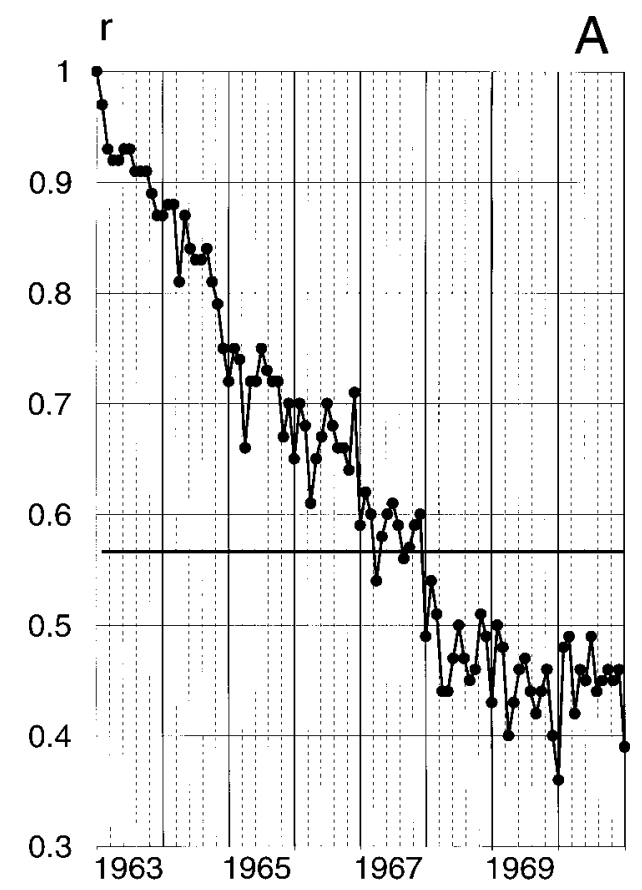

ference between the temperatures of surface water and air. The regression equation is:

$$
D M=63.06+0.17 M
$$

where $\mathrm{M}$ is a synthesis of the meteorological situation of the area, i.e.:

$$
M=(\Sigma W)^{1.5}(\Sigma A T)^{2} / \Sigma R
$$

where: $W=$ daily wind run $(\mathrm{km}), \Delta T=$ difference between mean daily water and air temperatures $\left({ }^{\circ} \mathrm{C}\right)$, and $R=$ daily solar radiation $\left(\mathrm{cal} \mathrm{cm}^{-2}\right)$.

The three meteorological variables and the surface water temperature were evaluated for the winter months only. To give more weight to their action during the last phase of the season, the variables were increasingly weighted: December $=0.5$, January $=0.7$ and February $=1$. We calculated the wind run only for winds stronger than a breeze ( $>50 \mathrm{~km} \mathrm{day}^{-1}$ speed $)$. In our lakes, the mixing phenomenon cannot be initiated by winds of a lower strength.

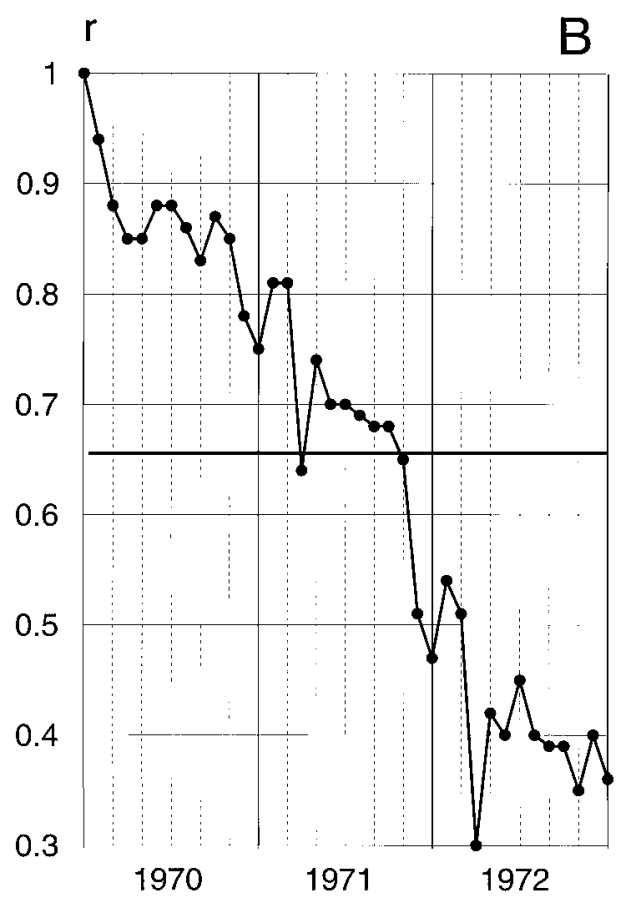

Fig. 2. Coefficients of correlation (r) for the autocorrelation functions of the deep water heat contents of Lake Maggiore after the complete vertical mixings of 1963 (A) and 1970 (B) with those of the following months.

As for the external forces determining the extent of winter mixing, analyses performed on some European lakes to define the relationships between deep water temperatures and some single meteorological parameters have not yielded any significant correlation's (Livingstone 1993). In Lake Maggiore we found a synergistic effect of different meteorological parameters on the depth of winter mixing $(D M)$. The model we propose includes solar radiation $(R)$, wind run $(W)$ and the dif-
The model was tested for each year from 1963 to 1998; the values of mixing depths obtained agreed fairly well with those resulting from direct measurements of the chemical and physical parameters of the water mass (Fig. 1). The correlation between the two data series is highly significant $(r=0.96 ; n=36)$. In addition, the parameter $M$ is highly correlated with the quantities of heat present both in the mixed water layer and in the deep layer at the time of the maximum winter mixing 
(Fig. 3): in the first case (A) the exponential type of correlation is direct $\left(r^{2}=0.82\right)$, while in the deep layer $(\mathrm{B})$, unaffected by mixing, the correlation is inverse $\left(r^{2}=\right.$ -0.86).

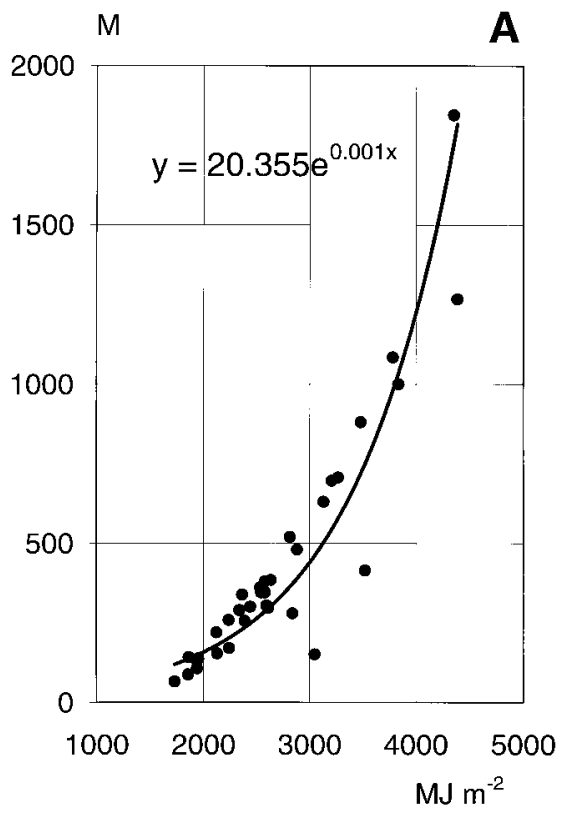

The heat exchange below the layers described above is due to other types of movement, such as local shears and internal waves (Welander 1968) which, however, behave in different ways and at variable depths from

Fig. 3. Correlation between the parameter $M$ and the heat content of the mixed layer (A) and that of the deep layer (B).

\section{VERTICAL TRANSPORT OF HEAT DURING THE YEAR}

We used pluriannual water temperature data to calculate the vertical distribution of the caloric content in 31 Italian lakes with depths varying between 10 and 410 $\mathrm{m}$; the calculation was based on the LIMNOX Program (1997) which was supplied by Bob Banens (University of New England, Armidale, NSW, Australia) and adapted for use with MS Visual Basic by Angelo Rolla (C.N.R-Istituto Italiano di Idrobiologia). Using this programme we calculated the total quantity, as well as the metre by metre distribution, from surface to bottom, of the caloric content, the Walker and Schmidt stabilities and the Birge work.

During the stratification period external conditions influence the water masses of deep lakes $\left(\mathrm{z}_{\max }>100 \mathrm{~m}\right)$ to a depth representing $14-16 \%$ of the maximum; $90 \%$ of the total energy accumulated each year is exchanged within this water layer, and below these depths, deep lakes are only partially affected by seasonal thermal events (Fig. 4). Heat exchange curves at various depths in 31 Italian lakes were obtained by fitting the experimental data to a power regression equation (for all power curves $r^{2}>0.91$ ); for each lake and each year, the percentage at various depths of the total heat exchange was evaluated. lake to lake (Michalsky \& Lemmin 1995). To evaluate the depth to which their action is felt, we correlated the values of the logarithms of the vertical turbulent mixing coefficients $\left(K_{z}\right)$ vs logarithms of the squared BruntVäisälä frequency $\left(N^{2}\right)$, calculated respectively using the following equations:

$$
K_{z}=a\left(N^{2}\right)^{b}
$$

being:

$$
\begin{gathered}
N^{2}=-(d \rho / d z)(g / \rho) \\
K_{z}=\left\{-1 /\left[A(z) \frac{\Delta T}{\Delta z}\right]\right\} \int_{z}^{z_{\max }} A\left(z^{\prime}\right) \frac{\Delta T}{\Delta t} d z^{\prime}
\end{gathered}
$$

where: $\rho$ is the density of water; $g$ is gravitational acceleration; $A(z)$ is the lake surface at depth $z, T$ is the temperature, $t$ is the time and $Z_{\max }$ is the depth of the lake.

The depth value, obtained from an examination of the correlation plots $\log K_{\mathrm{z}} v s \log N^{2}$, is $150 \mathrm{~m}$ in Lake Maggiore $\left(z_{\max }=370 \mathrm{~m}\right)$ on the pluriannual average (Fig. 5). The same depths in other lakes are: $180 \mathrm{~m}$ in Garda $\left(z_{\max }=350 \mathrm{~m}\right), 150 \mathrm{~m}$ in Como $\left(\mathrm{z}_{\max }=410 \mathrm{~m}\right)$, $100 \mathrm{~m}$ in Iseo $\left(\mathrm{z}_{\max }=258 \mathrm{~m}\right)$ and $75 \mathrm{~m}$ in Orta $\left(\mathrm{z}_{\max }=\right.$ $143 \mathrm{~m})$.

For each lake this value represents the depth of transition from a superficial to a deep hypolimnion. Up to 5- 


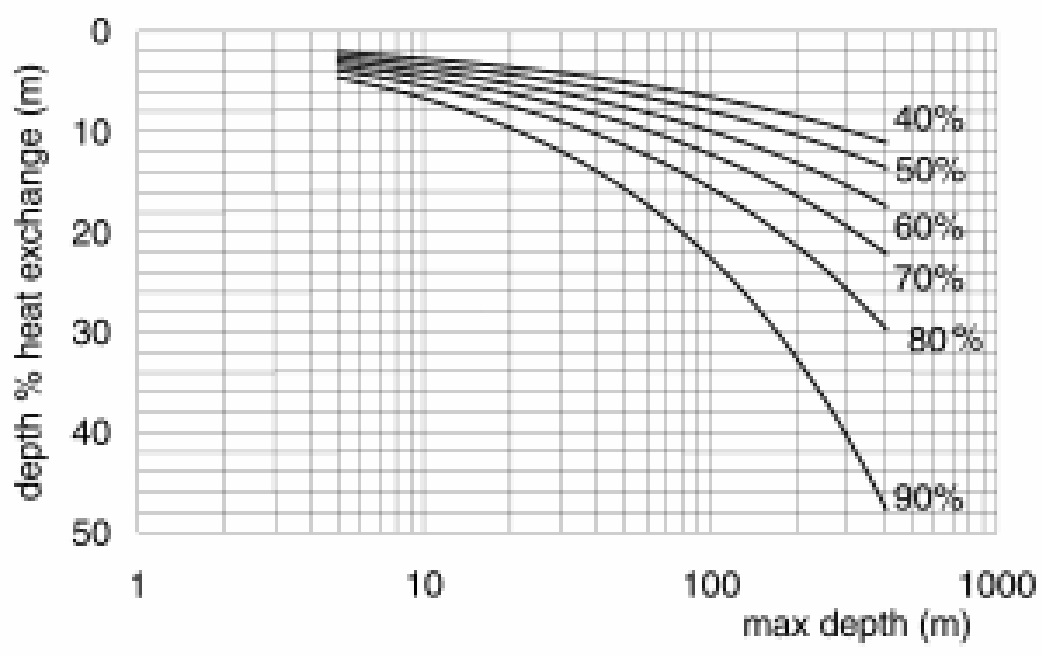

Fig. 4. Depths of different percentages of heat exchange in 31 Italian lakes.

$6 \%$ of the annual heat budget is accumulated in the former, while only $2-4 \%$ of the total can reach the deep hypolimnion. This happens during the March-May snow/ice-melt months (inflow of dense water from the tributaries) and in September-October (period of heavy rainfall).

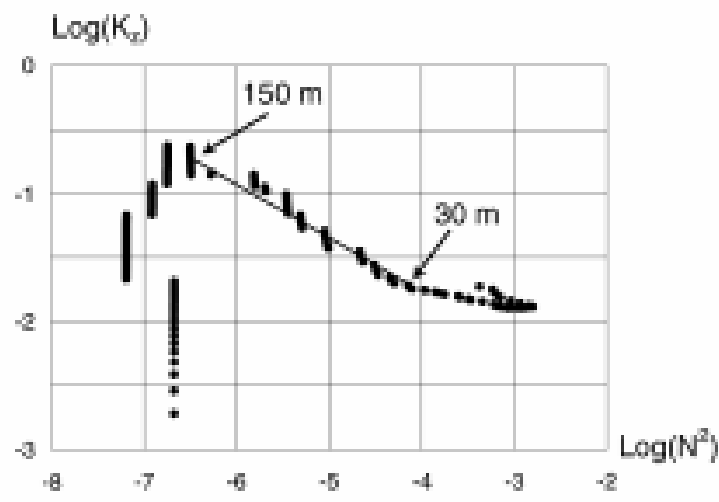

Fig. 5. Logarithm of the vertical mixing coefficients $\mathrm{K}_{\mathrm{z}} v s$ logarithm of the Brunt-Väisälä frequency $\mathrm{N}^{2}$ in L. Maggiore for the multiannual warming period from April to August. The depth of vertical mixing $(150 \mathrm{~m})$ is indicated from the straight line where $b=-0.42$ ).

In figure 6 the values in (A) represent the difference between the total heat content at the onset of stratification and at the end of the limnological winter. (B) shows the values relative to the autumn (difference between the heat content in October and September), when thermocline sinking takes place. All the data refer to 1995. At other times of year the deep hypolimnion can only be disturbed by exceptional hydrological events (Barbanti \& Ambrosetti 1990; Ambrosetti et al. 1982). The deep hypolimnion therefore represents the layer where a climatic memory is archived.

\section{THE CLIMATIC MEMORY IN DEEP LAKES}

The seasonal cycle of heat content in the various layers of Lake Maggiore is shown in figure 7. The results of an auto-correlation analysis (the correlation coefficient returns to a value of 0.913 after a 12 -month interval) confirm what is obvious at a glance: the seasonal cycle dominates in the surface layer $(0-50 \mathrm{~m})$; the deeper layers, on the contrary, are progressively less affected by seasonal variations, and show a general increase in heat over the last 36 years. This increase in the deep hypolimnion of the lake shows variations which fit into a longer time scale, perhaps comparable to that of changes in climate. This is how the deep waters retain a sort of "climatic memory", from which it may be possible to gain information on past and present climate changes. So, although only very little heat reaches the deep hypolimnion (as we have seen, $2-4 \%$ of the total heat budget), it is very important in defining the temporal variations of the "climatic memory" in deep lakes.

The heat content of the climatic memory of Lakes Garda and Orta (calculated at intervals of 15-30 days) also shows changes similar to those in Lake Maggiore (Fig. 8). From 1963 to 1998 there is a general increase, at the same rate for the three lakes, with a stasis of the positive trend from 1982 to 1986 . Very interestingly, the variations, whether positive or negative, marked or slight, appear contemporaneously in each of the three lakes; those of 1981 and 1991, caused by exceptional meteorological and hydrological events with the transport of surface water to the deep layer, are particularly striking. These events are also responsible for a sharp reduction in the positive trend of the climatic memory, by appreciably reducing the accumulation of energy. External events of this kind may temporarily modify the trend, but a return to the situation of the early years looks improbable. For example, the heat content currently present in Lake Maggiore at the end of the winter is around $5,193 \mathrm{MJ} \mathrm{m}^{-2}$, corresponding to a mean tem- 
A

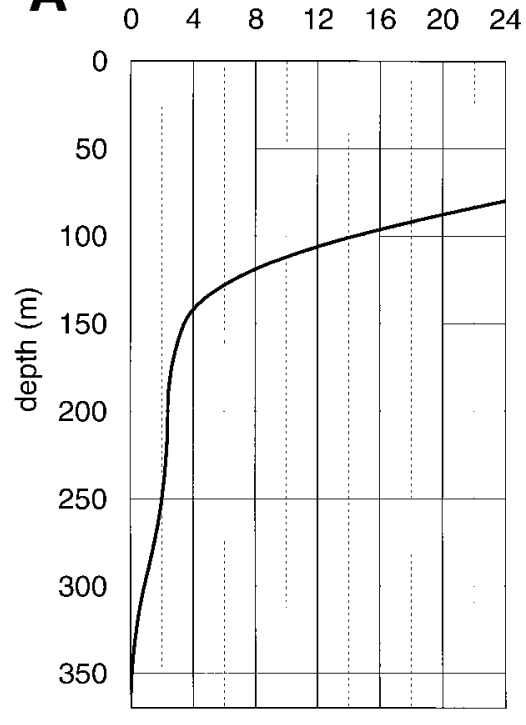

$\begin{array}{lllllll}\mathbf{B}^{\mathrm{MJ} \mathrm{m}^{-2}} & -16 & -12 & -8 & -4 & 0\end{array}$

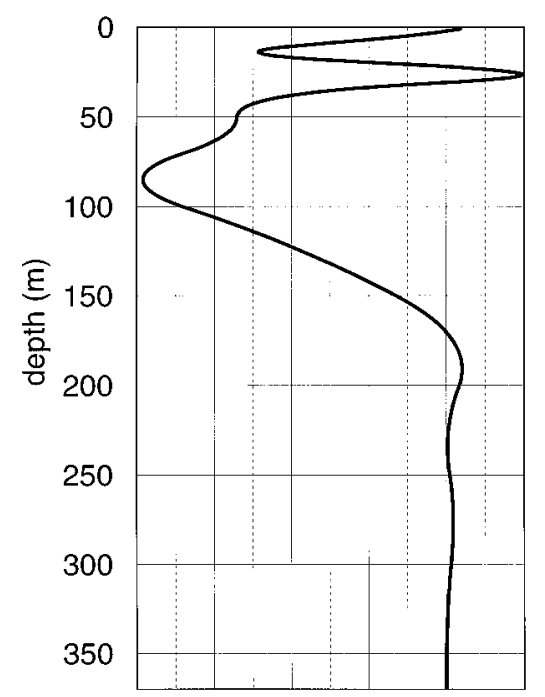

Fig. 6. Vertical profile of heat accumulation in Lake Maggiore during two different periods in 1995.
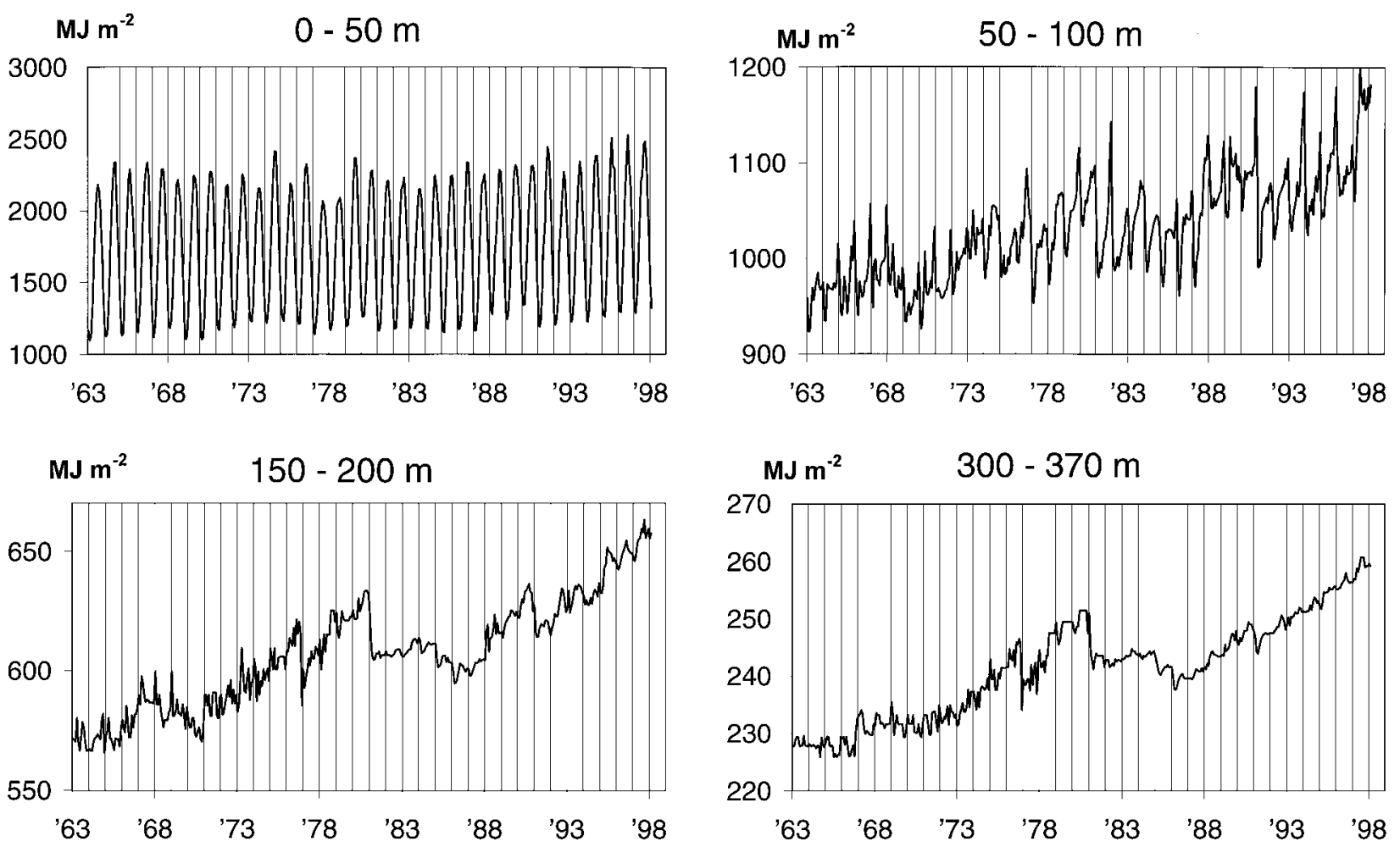

Fig. 7. Heat content in some layers of Lake Maggiore water column.

perature of $6.7-6.8{ }^{\circ} \mathrm{C}$ throughout the water column. This content was lower respectively by 630 and $840 \mathrm{MJ}$ $\mathrm{m}^{-2}$ in 1970 and 1963; to effect a complete vertical mixing, such conditions would require a huge amount of work, quantifiable in terms of Birge work of around $1,470 \mathrm{~J} \mathrm{~m}^{-2}, 10$ times greater than the 1963 figure, but without the possibility of returning to the initial thermal conditions, in which the mean temperature along the water column was $5.8^{\circ} \mathrm{C}$. Unless there is some sudden cooling, such a return to the initial conditions is rather unlikely, also because the heat increase has occurred in the deep hypolimnion.

The event of February 1999 should be mentioned here. After a winter characterised by a great deal of 
daily wind run and very low atmospheric temperatures, which had not been the case since 1970, Lake Maggiore underwent a complete overturn at a temperature of 6.63 ${ }^{\circ} \mathrm{C}$, which is very different from the temperatures in the years of previous overturns. The total heat content of the water mass thus went from $5193 \mathrm{MJ} \mathrm{m}^{-2}$ in winter 1998 to $4914 \mathrm{MJ} \mathrm{m}^{-2}$ on February $18^{\text {th }} 1999$, with a decrease of $5.4 \%$. The reduction in heat content in the layer containing the climatic memory was lower, stopping at $1439 \mathrm{MJ} \mathrm{m}^{-2}$ compared to the $1441 \mathrm{MJ} \mathrm{m}^{-2}$ measured in 1998. Further decreases in the total energy content of the lake occurred as the season proceeded: $4911 \mathrm{MJ} \mathrm{m}^{-2}$ on February $23^{\text {rd }}$ and $4885 \mathrm{MJ} \mathrm{m}^{-2}$ on March $1^{\text {st }}$, while the values on the same dates in the deep hypolimnion were 1433 and $1415 \mathrm{MJ} \mathrm{m}^{-2}$. From February $23^{\text {rd }}$ on, the decrease in heat content occurred almost exclusively in the layer containing the climatic memory $(-1.3 \%)$, following the sinking of colder water arriving from the tributaries, which took the mean temperature in this layer to $6.53{ }^{\circ} \mathrm{C}$. This was a consequence of the fact that after February $23^{\text {rd }}$ there was a period in which the atmospheric temperature was well above $13{ }^{\circ} \mathrm{C}$, thawing the snow which had fallen at relatively low altitudes. Eventually, on March $15^{\text {th }}$ the mean temperature in the deep hypolimnion stabilised at $6.51{ }^{\circ} \mathrm{C}$; this corresponds to a heat content in the climatic memory of $1410.6 \mathrm{MJ}$ $\mathrm{m}^{-2}$, only slightly less than that measured on the previous date and with similar values to those of winter 1996.

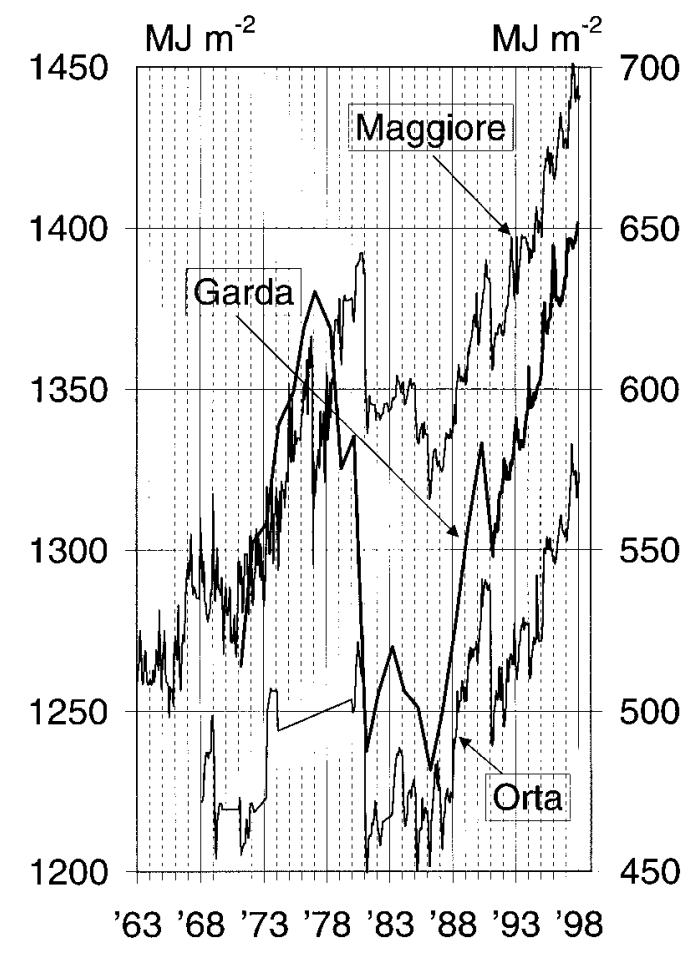

Fig. 8. Trends of climatic memories in lakes Maggiore, Garda and Orta, on the basis of approximately fortnightly data. Orta values on right y-axis.
As evidence of the regional nature of the phenomena, lakes Garda, Como and Orta, like Maggiore, also underwent complete overturns and a subsequent cooling of the deep hypolimnion. In particular, Lake Garda (N. Salmaso, pers. comm.) had a vertical mixing at a temperature of around $8.1{ }^{\circ} \mathrm{C}$ in February, and a sampling on March $9^{\text {th }}$ revealed, below a depth of $250-300 \mathrm{~m}$, a further cooling to $7.98{ }^{\circ} \mathrm{C}$ (similar to 1993 levels), accompanied by an oxygen concentration $3-4 \%$ higher than that measured between the surface and $250 \mathrm{~m}$.

The same set of phenomena was recorded for Lake Como (R. Mosello, pers. comm.), where the temperature in the deep layer measured on March $24^{\text {th }}$ was $6.75{ }^{\circ} \mathrm{C}$, similar to 1998 levels, with an oxygen concentration of $8.62 \mathrm{mg} \mathrm{l}^{-1}$.

Lake Orta, a shallower lake without major tributaries, had a complete overturn at the beginning of February at around $5.7^{\circ} \mathrm{C}$, similar to 1992 values (A. Calderoni, pers. comm.).

It was not possible to verify whether a complete overturn occurred in Lake Iseo, as the late winter data (L. Garibaldi, pers. comm.) were practically invalidated by the well-known meromictic conditions prevailing in the lake.

\section{TIME AND SPACE VARIATION OF CLIMATIC MEMORY}

To complete the description of the hydrodynamic situation in the deep Italian lakes, we also evaluated the heat content in the deep hypolimnion at the end of the limnological winter in lakes Como and Iseo. The climatic memories of each lake (Fig. 9) show a very similar trend and suggest that the event which has the greatest control over their evolution is the action of meteorological factors during the winter months; as we have seen, these determine the value of the coefficient $M$.

A stepwise multiple regression of the winter heat content in Lake Maggiore against the meteorological parameters used in determining the coefficient $M$, showed that the increase from 1963 to 1980 was due to wind, while during the second phase (1986-1998) it depended on a decrease in $\Delta T$ and in particular on a greater increase in air temperature than in the temperature of the surface water. In fact, since 1974 the quantity of winter wind on the Lake Maggiore area has decreased considerably (from 2000 to $700 \mathrm{~km}$ ). The winter air temperature increased by $0.015{ }^{\circ} \mathrm{C} \mathrm{y}^{-1}$ from 1963 to 1986, while from 1987 to 1998 the increase was 0.063 ${ }^{\circ} \mathrm{C}^{-1}$. It should further be noted that the temperature of the tributary waters has also risen by $1.5{ }^{\circ} \mathrm{C}$ in the last 10 years, which has contributed to warming the deep layer of the lakes.

An analysis of figure 9 confirms that the climatic memory in the other deep Italian subalpine lakes, as well as the dynamics of its formation, is identical to that of Lake Maggiore. This means that the same meteorological events have acted in the same way on other 
water bodies: as they belong to the same subalpine area, the meteorological action is likely to be similar, at least on a regional scale.

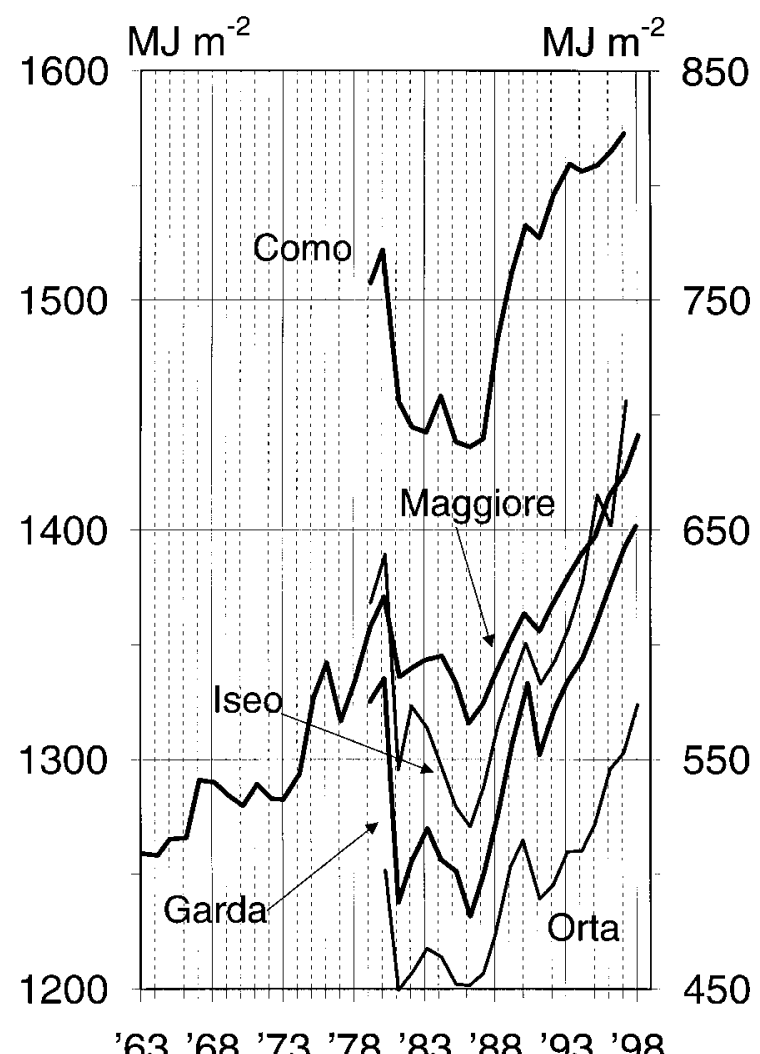

Fig. 9. Trends of climatic memories based on data collected at the end of the limnological winter in 5 deep Italian lakes. Lake Orta values on right y-axis.

Similar trends and abrupt changes have also been identified in historical records of deep water temperatures in some lakes north of the Alps (Livingstone 1993; Blanc et al. 1990). The temperature in the hypolimnion of another Italian lake, Lake Bolsena in Central Italy (Bruni1998), has increased by $0.9{ }^{\circ} \mathrm{C}$ since 1969. Gichuky (mimeograph) notes that the temperature in the hypolimnion of Lake Victoria (Kenya) has increased appreciably since the '50s, and links this with the current process of global warming.

In addition, the thermal data for the deep waters of the Mediterranean Sea below 2000 m (Betthoux et al. 1990) show not only a marked increase over the last thirty years, but also a certain coincidence with the most intense mixing events which have occurred in Lake Maggiore and other lakes north and south of the Alps (1963, 1970). The same phenomenon, albeit to a lesser extent, was found in the Central Greenland Sea in the column from 200 to $2000 \mathrm{~m}$ depth between 1980 and 1994 (Boenisch et al. 1998).
The conclusion we draw is that the hydrodynamic processes occurring in Italian water bodies depend on large-scale meteorological situations, and may be regarded as part of an ongoing process of global climate change.

The average water temperature of shallow lakes has also increased from year to year (Schindler et al. 1990), but the trend is often masked by the effect of seasonality or the presence of years with unusual meteorological situations, effects which are smoothed out in deep waters. The heat content and temperature of deep lakes are therefore as good indicators of the recent global warming as others such as melting glaciers, dendrochronology, increasing desertification and the rise in the sea level.

Apart from their usefulness as climatic indicators, these data are extremely important for the ecology of the lakes (Golley 1993), in particular as regards their water chemistry (balance between $\mathrm{CO}_{2}-\mathrm{HCO}_{3}-\mathrm{CO}_{3}$ ), their purely biological aspects, and their energetic characteristics, i.e. their exosomatic energy, according to Margalef (1974).

\section{REFERENCES}

Ambrosetti,W. \& L. Barbanti.1998. Osservazioni sull'idrodinamica del lago. In: CNR Istituto italiano di Idrobiologia, Ricerche sull'evoluzione del lago Maggiore. Aspetti limnologici, Campagna 1997 e rapporto quiquennale 19931997. Commissione Internazionale per la protezione delle acque italo svizzere: $57-59$.

Ambrosetti, W., L. Barbanti \& R. Mosello. 1982. Unusual deep mixing of Lago Maggiore during the winter 19801981. Geogr. Fis. Dinam. Quat., 5: 183-191.

Barbanti, L. \& W. Ambrosetti. 1990. The physical limnology on Lago Maggiore: a review. Mem. Ist. ital. Idrobiol., 46: 47-78.

Betthoux, J.P., B. Gentili, J. Raunet \& D.Tailliez. 1990. Warming trend in the western Mediterranean deep water. Nature, 347: 660-662.

Blanc, P., C. Corvi \& F. Papin. 1990. Evolution physicochimique des eaux du Leman. In: Rapp. Comm. Int. prot. eaux Leman contre pollut., Campagne 1988: 23-43.

Boenisch, G., J Blindheim, J. Bullister, P. Schlosser \& D.W.R. Wallace. (1998). Long term of temperature, salinity, density and transient tracer in the Central Greenland. Journal of Geophysical Research: (submitted).

Bruni, P. 1998. Monitoraggio del Lago: aspettando l'ossigeno. Il giornale del lago, 9:19-23.

Gichuki, J. The chemical environment of Lake Victoria (Kenya) with special reference to nutrients. Mimeograph: 4 pp.

Golley, F.B. 1993. An history of the ecosystem concept in ecology. Yale Univ. Press, New Haven: 254 pp.

Hutchinson,G.E. 1957. A treatise on limnology. Vol. 1. John Wiley and Sons. New York.

Livingstone, D.M. 1993 Temporal structure in the deep-water of four Swiss lakes: a short-term climatic change indicator? Verh. int. Ver. Limnol., 25: 75-81.

Margalef, R. 1974. Ecologia. Edicion Omega Barcelona: 950 pp.

Meybeck, M., P. Blanc, A.E. Moulherac \& C. Corvi.1991. Chemical evidence of water movements in the deepest part of Lake Leman. Aquat. Sci., 53(4): 273-289. 
Michalsky, J. \& U. Lemmin. 1995. Dynamics of vertical mixing in the hypolimnion of a deep lake: Lake Geneva. Limnol. Oceanogr., 40: 809-816.

Schindler, D.W., K.G. Beaty, E.J. Fee, D.R. Cruikshank, E.R. de Bruyn, D.L. Findlay, G.A. Linsey, J.A. Shearer, M.P. Stainton \& M.A. Turner. 1990. Effect of climatic warming on lakes of the central boreal forest. Science, 50: 967-970.

Sossau, C. \& R. Pechlaner. 1988. The regained but hidden holomixis of the Austrian Lake Traunsee. Verh. int. Ver. Limnol. 23: 74-79.

Received: March 1999

Accepted April 1999
Vollenweider, R.A.1964. Ueber oligomiktische Verhaltnisse des Lago Maggiore und einiger anderer insubrischer Seen. Mem. Ist. Ital. Idrobiol., 17: 191-206.

Welander, P. 1968 Theoretical forms for the vertical exchange coefficient in a stratified fluid with application to lakes and seas. Acta R. Soc. Sci. Litt. Gotheb. Geophys., 1: $1-26$. 